\title{
KUTATÁS A KÖZBESZERZÉSI KORRUPCIÓRÓL
}

\begin{abstract}
A GKI Gazdaságkutató Zrt. a Közbeszerzések Tanácsa (KT) megbízásából 2008-2009-ben kutatást végzett a hazai közbeszerzések területén kialakult korrupcióról. ${ }^{1}$ A cikkben a vizsgálatok néhány, a vállalati szféra számára fontos eredményét mutatja be a szerzố. Kiemeli, hogy a közbeszerzési korrupció mai gyakorisága a társadalom számára elfogadhatatlan mértékú károkat okoz, $\mathrm{s}$ a visszaélésekben részt vevố cégek számára is veszélyes, majd áttekinti a védekezés fóbb lehetôségeit.
\end{abstract}

\section{Kulcsszavak: közbeszerzés, korrupció, Magyarország}

A kutatás tárgyának pontos meghatározása igen nehéz, mivel a korrupció fogalmának nincs általános definíciója. A vizsgálatok során e normasértés három kulcsismérvének a következóket tekintettük: elkövetóje (1) közvetlen vagy közvetett ön- vagy csoportérdekból (2) megszegi a közösségi együttélés egy vagy több olyan szabályát, amelynek érvényesítéséért felelős, s ennek során (3) legalább egy további féllel, magánszemélylyel vagy intézményi képviselővel összejátszik. A közbeszerzési korrupció pedig olyan korrupt tevékenység, amely (4) közbeszerzéssel kapcsolatos, vagy ilyen eljárást kerül meg. E nehézkes fogalomértelmezés azonban (Hankiss E. véleményét ${ }^{2}$ igazolva) a vizsgálatok során nem okozott alapvetó gondokat.

A munka fó feladata az volt, hogy tudományosan megalapozott képet kapjunk és adjunk a hazai közbeszerzési eljárásokban kialakult korrupciós jelenségek jellemzóiról, illetve a korrupció elleni védekezés lehetőségeiról és módszereiról. Elsősorban a korrupció, valamint a közbeszerzési korrupció hazai gyakoriságát, az utóbbi visszaélések előfordulási formáit (típusait), okait, hatásait, valamint a védekezés lehetőségeit kellett tisztáznunk. Mindezek érdekében a GKI Gazdaságkutató Zrt. kereteiben a következő részfeladatokat oldottuk meg: a friss nemzetközi és hazai szakirodalom áttekintése, 2002 és 2007 között a legfontosabb hazai napi- és hetilapokban, illetve a fóbb tudományos igényú periodikákban a témáról megjelent mintegy háromnegyed millió sajtóközlemény feldolgozása, 120 mélyinterjú elkészítése a közbeszerzésben résztvevők körében, a MÁST Kft. által készített 900 fôs szociológiai felmérés eredményeinek áttekintése, és a fóbb megállapítások és következtetések összefoglalása. A kapott eredmények összességében kedvezôtlen helyzetképet vázoltak fel, éles vitákat is kiváltottak, de mindenben alátámasztották a korrupcióellenes küzdelem fontosságával kapcsolatos hazai nézeteket.

\section{A közbeszerzési korrupció méretei}

A kutatás szerint a korrupció a közbeszerzési eljárásoknak igen súlyos gondja. A kapott eredmények alapján azt valószínúsítettük, hogy bár a korrupció a magyar gazdaságban általában csak „közepesen” gyakori ${ }^{3}, a$ hazai közbeszerzési folyamatokat nagyobb gyakorisággal sújtja, az eljárásoknak nagyobbik felét - idószakonként, gazdasági szféránként változóan mintegy kétharmadukat-háromnegyedüket (63-75\%-ukat) - befolyásolja. Ezt egyetlen, közbeszerzésekkel kapcsolatba kerülő vállalat se hagyhatja figyelmen kívül.

Ismeretesek ugyan a fenti becslésünknél magasabb, illetve alacsonyabb értékeket hangoztató vélemények is. A magas számok ${ }^{4}$ indokoltságának az érzetét kelti például, hogy sajtónk olvasói átlagosan heti két-háromszor szembesülhettek - autópályák, vagy a metró építésével, Combino villamosok, kakaóbiztos számítógépek beszerzésével, túzijáték megszervezésével stb. kapcsolatos cikkekben - a közbeszerzési korrupció jelenségével. Esetenként azonban a korrupciós gyanú (vádak) túl gyakori voltával kapcsolatos jelzéseket is kaptunk. Például egyes interjúalanyaink olyan eseteket is említettek, melyeknél nem volt korrupció, az idôzavar stb. miatt alkalmazott sajátos eljárási technikák nyomán mégis meggyanúsították ôket ezzel. De a miénknél alacsonyabb becslésnek 
is vannak hívei, így a közbeszerzési eljárásokban résztvevôkkel készített interjúk alanyai szerint a korrupció „csak” a hazai eljárások 40-50\%-át fertôzi. Gyakran érzékelhetố volt azonban, hogy a jelzett tájékoztatást adó „óvatos”, konkrét információk hiányában nem kívánja cégét, kollégáit stb. törvénysértéssel vádolni, illetve a magyar értelmiség egyes köreiben kialakult, a problémákat elhallgató gyakorlatot követi.

A vizsgálódás a korrupciós cselekmények fóbb típusaira is rámutatott. Kiemelkedó súlyúaknak találtuk a politikával, így a pártfinanszírozással összefüggó gondokat (jellemzônek ítélve például, hogy az elmúlt években a korrupció kérdéskörét érintő hazai sajtócikkekben a politika szó volt a leggyakoribb kifejezés, minden második megvizsgált írásban megtaláltuk ${ }^{5}$ ), de azt is megállapítottuk, hogy a korrupciós motivációk közt az ,üzleti” meggondolások is sajnálatosan gyakoriak. Mind a közbeszerzési hirdetmények kiírói (a jogi szakzsargon szerint: az ajánlatkérók), mind a pályázók (ajánlattevôk) igen találékonyaknak bizonyulnak korrupciós együttmúködésük célszerú módjának a kialakításában (1. táblázat).
De gyakorinak bizonyultak a pályázók (és ,,alvállalkozóik") közti korrupt együttmúködésnek - így az ún. kartellezésnek - egyes formái is (2. táblázat).

A táblázatok információi csak nagy óvatossággal értelmezhetők. Hiba lenne például, ha arra következtetnénk belólük, hogy a hazai érdekeltek számos, a nemzetközi korrupciós gyakorlatban nem ismert technikát alkalmaznak - hiszen a hivatkozott OECD-tanulmány nem állította, hogy típuslistája teljes körú. Nem árt az óvatosság a módszerek felhasználásának gyakoriságával kapcsolatos számok esetében sem, hiszen nem felejthetjük a válaszok „óvatos” jellegét. Azért, mert egyetlen interjúalany sem állította például, hogy cége, ha lehet, elkerüli a közbeszerzési eljárás kezdeményezését, bár hirdetményt adott közre, a nyertest előre eldöntötte, a kiírástól eltérô ajánlatot is elfogadott, elmulasztott jogorvoslatot kérni, vagy pályázatában ajánlatadóként a munkába bevonni nem kívántakat is szerepeltetett, még aligha állítható, hogy ezek a hazai eljárásokban ismeretlen mesterfogások. A hosszú típuslista információi mindezek ellenére is fontosak, figyelemfelhívó jellegúek, sokban járulhatnak hozzá a

\section{1. táblázat}

\section{Az ajánlatkérô és az ajánlattevő(k) összejátszásával létrehozott} korrupció típusai*

\begin{tabular}{|c|c|c|c|c|c|}
\hline & OECD & Egyéb & \multicolumn{2}{|c|}{ GKI-mélyinterjúk } & \multirow{2}{*}{$\begin{array}{c}\text { MÁST- } \\
\text { felmérés } \\
\text { besorolása } \\
* *\end{array}$} \\
\hline & \multicolumn{2}{|c|}{ említés } & mintája* & $\begin{array}{c}\text { említési gyako- } \\
\text { riság \% }\end{array}$ & \\
\hline Nyomásgyakorlás egy ajánlattevő sikeréért & & $\mathrm{x}$ & Teljes & 23 & \\
\hline Vesztegetés egy ajánlattevő sikeréért & & $\mathrm{x}$ & Teljes & 8 & \\
\hline Vesztegetés magas ár elfogadásáért & & & Teljes & 19 & \\
\hline Közbeszerzési eljárás elkerülése & $\mathrm{x}$ & $\mathrm{x}$ & & & $S$ \\
\hline \multicolumn{6}{|l|}{ Hamis célt rögzító ajánlatkérés } \\
\hline Az ajánlattevők körének korlátozása & $\mathrm{x}$ & $\mathrm{x}$ & Teljes & 36 & $\mathrm{~S}$ \\
\hline Színlelt (a nyertest előre eldöntô) kiírás & $\mathrm{x}$ & $\mathrm{x}$ & & & $\mathrm{S}$ \\
\hline Ajánlattevő exkluzív informálása & $\mathrm{x}$ & $\mathrm{x}$ & Teljes & 8 & Á \\
\hline Ajánlattevő indokolatlan kizárása & & & A. tevôk & 17 & $S$ \\
\hline Hamisan indokolt eredménytelenség & & $\mathrm{x}$ & & & \\
\hline Ajánlat részrehajló értékelése & $\mathrm{x}$ & $\mathrm{x}$ & & & \\
\hline Kiírástól eltéró ajánlat elfogadása & & $\mathrm{x}$ & & & \\
\hline Szerződés indokolatlan módosítása & & & A. tevốk & 3 & \\
\hline Szerződéstôl eltérő teljesítés elfogadása & $\mathrm{x}$ & & A. tevốk & 7 & \\
\hline Alacsony ajánlati ár indokolatlan kiegészítése pótmunka stb. címén & & $\mathrm{x}$ & & & \\
\hline Jogorvoslatkérés elmulasztása & & $\mathrm{x}$ & & & \\
\hline
\end{tabular}

* A szakirodalom és a GKI-mélyinterjúk a korrupciós esetekben alkalmazott megoldásokról tájékoztattak. A MÁST felvétel viszont arra kérdezett rá, hogy a technika alkalmazása korrupcióra utal-e.

** Á: a legtöbb válaszadó, T: a válaszadók többsége, S: sokak által korruptnak vélt magatartás. 
Az ajánlattevốk (és alvállalkozóik) összejátszásával létrehozott korrupció típusai

\begin{tabular}{|c|c|c|c|c|c|}
\hline & OECD & Egyéb & \multicolumn{2}{|c|}{ GKI mélyinterjúk } & \multirow{3}{*}{$\begin{array}{c}\begin{array}{c}\text { MÁST } \\
\text { felmérés } \\
\text { besorolása } \\
* *\end{array} \\
\text { Á }\end{array}$} \\
\hline & \multicolumn{2}{|c|}{ említés } & mintája* & $\begin{array}{l}\text { említési gyako- } \\
\text { riság \% }\end{array}$ & \\
\hline Ajánlattevő több cége ad ajánlatot & & & & & \\
\hline Előzetes (kartell)megállapodás & $\mathrm{x}$ & $\mathrm{x}$ & Teljes & 13 & $S$ \\
\hline $\begin{array}{l}\text { A munkába bevonni nem kívánt szerepeltetése } \\
\text { alvállalkozóként }\end{array}$ & $\mathrm{x}$ & & & & \\
\hline Megállapodás minőségrontás elhallgatásáról & & & Teljes & 2 & $\mathrm{~S}$ \\
\hline
\end{tabular}

* A szakirodalom és a GKI-mélyinterjúk a korrupciós esetekben alkalmazott megoldásokról tájékoztattak. A MÁST felvétel viszont arra kérdezett rá, hogy a technika alkalmazása korrupcióra utal-e.

** Á: a legtöbb válaszadó, T: a válaszadók többsége, S: sokak által korruptnak vélt magatartás.

visszaélések elleni védekezés sokoldalúságához. Igencsak elgondolkodtató, a tennivalók bonyolultságát jelzó hír a MÁST-felmérésnek az a tájékoztatása is, hogy egyes típusok alkalmazását számos válaszadó nem is ítéli korrupciós cselekménynek.

\section{A korrupció hatásairól}

A mai szakirodalom egyértelmúen súlyosnak ítéli a korrupció következményeit. Kétségtelen ugyan, hogy amikor mintegy 30 éve Hankiss Elemér a korrupció hazai gondjairól írt, az erôs feketekávé érdekében a talán 3 forintos számla mellé adott plusz egy forintot választotta példának. ${ }^{6}$ Azóta azonban sok víz folyt le a Dunán, s a „tétek” tárgykörünkben is nóttek.

Napjainkban az elméleti elemzések és gyakorlati tapasztalatok egyaránt azt igazolják, hogy a gazdálkodás kereteit megszabó - kiemelten a tulajdonhoz és a szerződésekhez fúződő - egyes „intézmények”, így a korrupciós cselekmények is a gazdasági haladás (növekedés, fejlődés) ütemét meghatározó fontos tényezók. A kutatás ugyanakkor arra is rámutatott, hogy a jelzett megállapítások idehaza még nem kellően ismertek, illetve elismertek. Sót, azt tapasztalhattuk, hogy egyes hazai szakértớk még azt a számos irányadó kutatás által megfogalmazott megállapítást is vitatják (valójában tudományos alap nélkül), hogy a korrupció jelentősen növeli jelenlegi gazdasági bajaink súlyát, $\mathrm{s}$ az adott felfogásmód olykor a hatékony védekezést is nehezíti.

Már a gazdasági fejlettség és a korrupció kapcsolatának első matematikai-statisztikai vizsgálata ${ }^{7}$ is erôs negatív korrelációt állapított meg - „keresztmetszeti” adatok alapján - a ,fejlettség" (az egy fóre jutó GDP), illetve a korrupció szintje közt. Mind a további nem- zetközi kalkulációk, mind a módszer hazai adaptációi ${ }^{8}$ azonos eredményt mutattak. A részletező vizsgálatok a magyarázatokra is utaltak. Bizonyítást nyert például, hogy a korrupció mérsékli a fejlesztési célú gazdasági forrásokat (áttereli a közkiadásokat a szükséges múködtetési és felújítási céloktól az új létesítmények, berendezések beszerzése felé, s növeli a közfinanszírozású beruházások nagyságát, mert ily módon növelhetố a kenôpénzek esélye).

Ennél is súlyosabbak lehetnek az általános társadalmi károk. A korrupcióval erósen fertózött társadalmakban például az átlagosnál gyakrabban kerülnek alkalmatlan személyek a közigazgatási pozíciókba, s nőnek hozzá nem értésüknek, illetve törvénysértő akcióiknak a kárai. A kölcsönös kedvezmények és engedmények egyes társadalmakban már a politika egészét áthatják, s a gazdaság egészét is uralhatják. Sérülnek továbbá a demokratikus társadalmaknak, kiemelten a részrehajlásmentes állami közigazgatásnak az alapértékei, így az átláthatóság, nyilvánosság, elszámoltathatóság, s romlik a társadalom értéktudata: a társadalom tagjai úgy gondolják, hogy a maguk terepén nekik is szabad a pálya, rájuk sem vonatkoznak a ki nem kényszeríthetô szabályok. Sớt, még a jövő generációja is torzul, a tisztességtelen előnyök növekvô sikeresélyei eltérítik a diákokat a múszaki pályákról, hiszen a jog tanulása sokkal jobb kilátásokat ígér ${ }^{9}$ stb. Vizsgálataink szerint mindennek a jelei a magyar társadalomban is kimutathatók.

De a korrupció vállalatokat sújtó hatásai sem kisebbek, mint a fenti makrogazdaságiak. A GKI mélyinterjúi során megkérdezett négy csoport tagjai négy jól elkülöníthetố csoportba sorolták a korrupció e hatásait (volt közöttük olyan, aki egyáltalán nem említett ilyet, volt, aki többet is megnevezett) (1. ábra). 
A korrupció hatásai a válaszadók szerint

(említési gyakoriságok a válaszadói csoportokban)

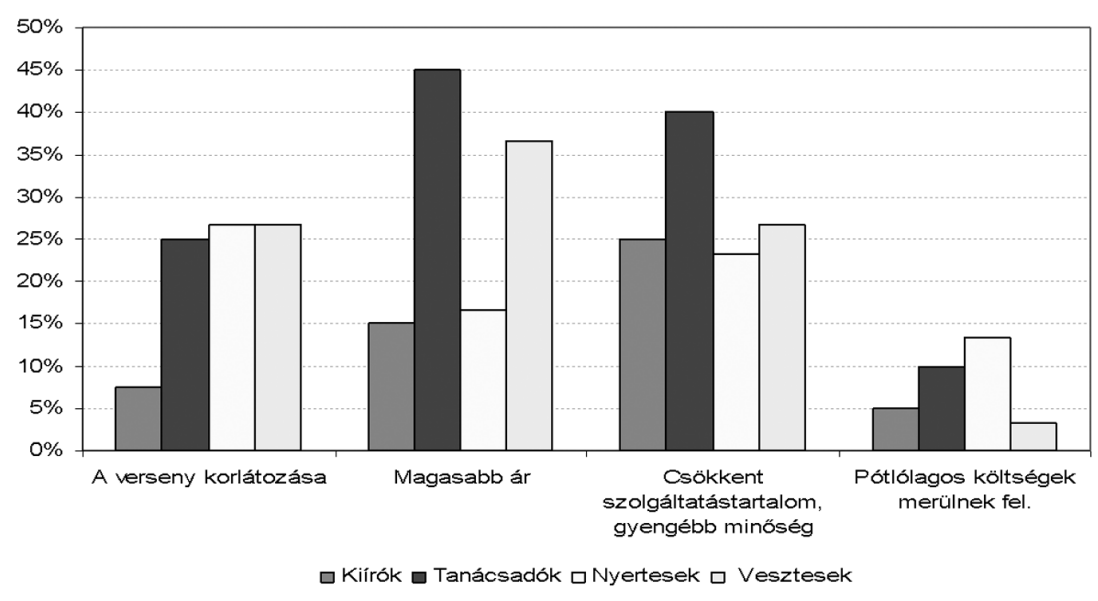

Forrás: a kérdőív nyílt kérdéseire kapott válaszok feldolgozása

A versenykorlátozás leggyakoribb technikája az, hogy az ajánlatkérő a közbeszerzési eljárás feltételrendszerét úgy állítja össze, hogy a közbeszerzési eljárásban az általa preferált cég eleve elônyt élvezzen, vagy akár más, nyerésre esélyes cég ne is tudjon indulni (illetve, hogy nyílt közzététel nélküli eljárást alkalmaz). Ugyancsak gyakori azonban az ajánlattevớk összejátszása (a kartellezés), melynek során a nagyobb szállítók olykor akár fel is osztják egymás között a piacot. Mindez elsősorban a kkv-szférát szorítja ki a versenyból. A visszaélés jelentős kára két tényezô eredménye. Egyrészt súlyos következményekkel jár az is, hogy gyakran van szó nagy összegú üzletekról, hiszen ekkor a károk is hatalmasak lehetnek. Másrészt növelik a károkat a versenykorlátozás tovagyưrüző hatásai; hiszen a projektek megvalósulási módja gyakran meghatározza a további múködtetés, továbbfejlesztés során eséllyel indulók körét is (bevett trükk például olcsó ajánlattal megnyerni egy pályázatot, majd egyetlen hozzáértốként borsos karbantartási, múködtetési, tanácsadási szerződést is nyerni mellé).

Senki nem vitatja, hogy a kenôpénz, vagy ,alkotmányos költség" - amely az ár kisebb-nagyobb százaléka lehet $^{10}$ - mindig beépül az árba. Mind a szakirodalom szerzői, mind interjúadóink egyetértenek azonban azzal, hogy a korrupció árnövelő hatása gyakran sokszorosan meghaladja a kenópénz nagyságát. Ez nyilvánvaló is azokban az esetekben, ahol a visszaélés célja éppen az ár növelése, valamely „monopolár” elérése. Sokszor azonban a legnagyobb károkat nem is ez, hanem a viszszaélések következtében keletkező veszteségek (például: felesleges beruházások, a szakszerútlen vezetés miatti költségnövekedés stb.) okozzák. Feltehetően ez utóbbiak magyarázzák a hazai autópálya-építésnek a
1. ábra nemzetközileg szokásosnál magasabb költségeit, vagy azt, hogy a budapesti metró építése a spanyol költségszint ötszörösébe kerül stb.

Korrupt közbeszerzés esetén legtöbbször a megvalósuló projekt jó minősége sem biztosítható. Sokszor éppen a minôségi engedmény, az ellenőrzés lazasága a korrupció (egyik) tárgya. De a „megkent” közbeszerzőnek többnyire akkor is kockázatos (s az egészen korrupt társadalmakban lehetetlen is) a hibás teljesítés reklamálása, vagy a garanciális, szavatossági jogok érvényesítése, ha ez nem is szerepelt a korrumpálóval kötött megállapodásban. E tárgykört illetően a közelmúltbeli magyar sajtóban talán a Combino villamosok ügye szerepelt a leggyakrabban, de számos további eset ismertetése is megjelent.

Az elmondottak is alátámaszthatják a korrupció hazai kárainak évi sok százmilliárdos, esetenként akár ezermilliárdos nagyságára vonatkozó becsléseket.

Végül szólnunk kell arról is, hogy a magyar gazdaságban nem ritka az olyan korrupt közbeszerzési eljárás sem, amelyik sokak szerint nem okoz károkat. Ilyen eset, ha a kiíró azért kezd versenykorlátozó eljárást, mert a jól bevált alvállalkozóval kíván (például a hatékony és gyors munkavégzés miatt) együttmúködni, s túl kockázatosnak ítéli az ismeretlen céggel való együttmúködést. De a kartellezés oka lehet a közbeszerzési törvény valamely bürokratikus kötöttségének - így indokolatlan kapacitáskikötésének - az elhárítása is. Ekkor kétségtelen, hogy a tisztességtelen eljárás sem minőségben, sem árban nem okoz veszteséget. E megoldás sem értékelhetô azonban pozitívan, hiszen ha az ésszerú gazdasági megoldások követését gátló szabályozás hatására a kibúvók (kiskapuk) keresése válik megszokottá, ez lehetetlenné teszi a társadalmilag elfogadható, illetve elfogadhatatlan akciók megkülönböztetését, s ezzel értékválság kialakulására (vagy további elmélyülésére) támaszt veszélyt.

\section{A védekezés lehetôségeiról}

Ma már talán nincs is magyar szakértô, aki (az elmúlt évtizedek számtalan kampánya ellenére) megkérdőjelezné, hogy fokoznunk kellene a korrupció és a közbeszerzési korrupcióellenes erőfeszítéseinket. De az eddigieknél erőteljesebb védekezést több fontos nemzetközi intézmény és üzleti partnerünk is elvárja. ${ }^{12}$ A lehetőségekról és a kívánatos konkrét tennivalók- 
ról azonban nem alakult ki egyetértés. A mai felfogásmód a korrupció elleni védekezésnek két alapvető módszer-csoportját különbözteti meg. Az egyik az integritás (integrity), ami az emberi cselekedetek belsố indítékaira - a becsületességre, megbízhatóságra, erkölcsi tartásra stb. - koncentrál, azon szemléletbeli és magatartási jellemzók összességét helyezi előtérbe, amelyek a gazdasági szereplóket képessé teszik arra, hogy döntéseiket az elvárt erkölcsi és előírt normáknak megfelelốen hozzák meg. A másik az ún. megfelelôség (compliance), ami a jogi és egyéb szabályozási normáknak megfelelő cselekvést, az erre ösztönzést/ kényszerítést jelenti, s a magatartásformákat befolyásoló külsó erókre - a jogi szabályozásra, a vizsgálatokra, ellenôrzésekre, szankciókra - koncentrál. S úgy tûnik, a hazai illetékesek (indoklás nélkül) nagyobb fontosságot tulajdonítanak az elsố csoport hatásainak, kiemelten az ezeket múködésbe hozó, az áttekinthetóség, nyilvánosság révén közvetetten korrekt ügyintézésre mozgósító eróknek, mint a környezet közvetlen szabályozásának.

Feladatkijelölő értékúnek véljük ugyanakkor, hogy az OECD (2007) a korrupció elleni küzdelem három alapvetố fontosságú lépéseként jórészt a külsố hatótényezókkel kapcsolatos erófeszítéseket szorgalmaz. Konkrétan a következóket említi:

- megfelelően érvényesített, világos szabályokat és alapos szankciókat kell kimunkálni, hisz ez a korrupció elleni harc egyik leghatékonyabb eszköze;

- a korrupció és a vesztegetések hatékonyabb megelőzése és felderítése érdekében jogi és nem jogi készséggel rendelkezó szakértók hálózatát kell kiépíteni;

- a hivatalnokok körében tudatosítani kell a korrupció és a vesztegetés káros hatásait, javítani kell a megfeleló eljárási szabályok ismeretét, és bővíteni kell alkalmazásaik körét;

Hasonlóak a TI (2007) ajánlásai. E dokumentum az alábbiakat sürgeti:

a) a közbeszerzési intézmények dolgozzanak ki etikai kódexet, amelyben az intézmény és alkalmazottai vállalják a korrupció elleni következetes harcot;

b) az intézmény rögzítse, hogy csak olyan cégek közbeszerzési pályázatát fogadja el, amelynek van hasonló kötelezettségvállalást tanúsító etikai kódexe;

c) készítsék el azoknak a cégeknek a feketelistáját, amelyekról nyilvánvalóvá vált, hogy korrupciós ügyletekbe keveredtek, vagy fogadják el egy nemzetközi intézmény hasonló listáját - s a listán szereplôket meghatározott időre zárják ki a közbeszerzési lehetóségekből;

d) a felek a közbeszerzési szerződésekben - és a fővállalkozó, illetve az alvállalkozók közti szerzôdésekben is - vállalják a korrupciót elkerülő magatartást;

e) nyílt versenytárgyalás előzzön meg valamennyi, egy nem túl magas értékhatárt meghaladó közbeszerzést, a kivételek indoklása legyen világos;

f) valamennyi pályázó - és lehetôség szerint a közvélemény is - könnyen jusson hozzá a szerződéskötést megelôző minden lépéssel, a versenytárgyalási lehetőségekkel, a bírálati szempontokkal, az értékelési eljárásokkal, a döntésekkel és indoklásukkal, a szerződési határidôkkel és feltételekkel, a szerződés végrehajtásával, a közremúködốk és ügynökök szerepével és a jogorvoslati lehetőségekkel kapcsolatos információkhoz, s csak a törvények által titkosnak minősített információk legyenek bizalmasan kezelhetốk;

g) egyetlen pályázó se juthasson hozzá olyan információhoz, amit a versenytársak nem kaptak meg;

h) a pályázóknak legyen elegendő idejük a pályázat kidolgozására, ugyancsak elegendő idő álljon rendelkezésre a pályázatok elfogadása és a szerződéskötés között arra, hogy az elutasítottaknak legyen módjuk kifogásaik beterjesztésére;

i) a szerződés nagyobb (például a szerződéses értéket 15\%-kal meghaladó) megváltoztatására csak magas szinten - lehetóleg csak a szerződést aláírók jóváhagyásával - legyen lehetőség;

j) a belsố és külsố ellenőrző, auditáló szervek legyenek függetlenek, és jelentéseik legyenek nyilvánosak, minden indokolatlan késés esetén automatikusan induljanak be ellenőrzô mechanizmusok;

k) az elókészítés, a pályázatok bírálata, a szerződéskötés és a megvalósítás ellenőrzése legyen különböző testületek feladata;

1) a közbeszerzéseket lebonyolító kollektíva legyen jól képzett és kellően megfizetett, s szervezeti megoldások (így a bizottsági döntési gyakorlat bevezetése és az illetékesek rotációja) erôsítsék megbízhatóságukat;

m) a civil szervezetek, mint a versenytárgyalások és a megvalósulás független megfigyelói, kapjanak lehetôségeket az eljárásokban való részvételre (i. m. 4-6. oldal). 
Nyilvánvaló, hogy a vázolt, s a vizsgálatunk tapasztalatai nyomán megfogalmazott hasonló javaslatok jelentős része központi gazdaságirányítási tennivalókat ${ }^{6}$ fogalmaz meg. Ezeket elsôsorban az illetékesek körében ismertettük. A következókben viszont a vállalati feladatokat vázoljuk. Ezek többsége nem új (sốt, a nemzetközi szakirodalomban már jól ismert) ugyan, de hazai adaptációjukra még legfeljebb kivételesen került csak sor.

A közbeszerzési ajánlatkérók számára adott ajánlásaink az alábbiak:

- Alakítsák ki korrupcióellenes politikájukat.

- A vezetók tekintsék feladatuknak, hogy „tisztakezü” személyekre bízzák a közbeszerzések ügyeinek az intézését - és tegyék lehetôvé, hogy a megbízottak rendszeres továbbképzés során megismerjék a korrupcióellenes küzdelem új és új meggondolásait, módszereit.

- Kerüljék (miként ezt a hazai kkv-k interjúink során többször javasolták) a túlzottan sokrétú feladatokkal kapcsolatos ajánlatkérést, ha van rá mód, kérjenek önálló ajánlatokat az egyes részfeladatokra.

- Törekedjenek rá, hogy ajánlatkérésük egyszerú ajánlattételt tegyen lehetővé, kerüljék a már ismert, illetve a bírálat szempontjából felesleges információk bekérését. Ne írják elő, hogy az ajánlattevő szerezze be az államigazgatás területén már megtalálható információkat. Minimalizálják az „,eredeti” igazolások bekérését: például honosítsák meg az EU azon gyakorlatát, amely az ajánlattételhez csupán kevés referenciát kér, s csak a nyertes esetében, a szerző́déskötés előtt igényli az ajánlattevő alkalmasságát igazoló jogi dokumentumokat.

- Minden esetben követeljék meg, hogy az ajánlattevók és alvállalkozóik rendelkezzenek a korrupció elleni stratégiájukat rögzító etikai kódexszel. A minôsített (s így az elóző követelményt is teljesítô) ajánlattevốk számára viszont tegyék lehetôvé a lehető legkevesebb adminisztratív terhet jelentő ajánlattételt.

- Bóvitsék az elektronikus közbeszerzés alkalmazási körét. Ha van mód rá, alkalmazzák például az ajánlatkérók és ajánlattevớk közti korrupció, illetve a különbözó ajánlattevók közti kartellezés
2. ábra

A közbeszerzési eljárások ellenôrzésénél

viszonyított hányada, \%

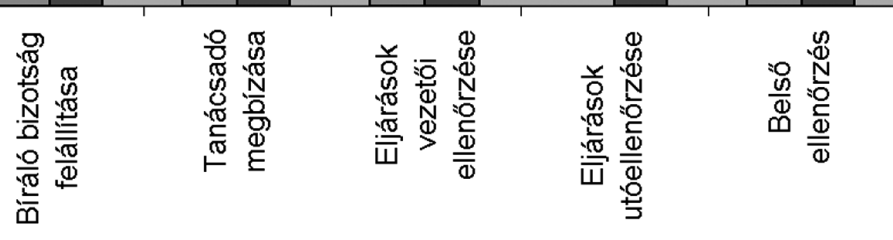

$\square$ gyanú volt $\square$ gyanú nincs

nterjúk

lehetőségeit egyaránt erôteljesen szúkítő elektronikus ,árlejtés” (licit) technikáit. Tegyék gyakorivá azt az alkalmazást is, amikor az ajánlattevőktól nem az ár csökkentését, hanem az ajánlat ,,múszaki” tartalmának erősítését várják.

- A felkészületlen (és indokolatlanul alacsony árakat megjelölő) ajánlattevók visszaszoritása érdekében növeljék a bírálati szempontok közt a „múszaki" követelmények - és a referenciák - súlyát.

- Fordítsanak a jelenleginél lényegesen nagyobb figyelmet az általuk indított közbeszerzési eljárások monitoringjára. A monitoringrendszer keretében építsenek ki a korrupció veszélyére figyelmeztetố alrendszert.

- Ne mulasszák el a befejezett projektek (külsó intézmények által végzett) auditját.

- Készítsenek és tegyenek nyilvánossá feketelistát profiljuk korrupt ajánlattevőiról.

Javaslatok az ajánlattevónek:

- Alakítsák ki korrupcióellenes politikájukat.

- A vezetốk tekintsék feladatuknak, hogy „tisztakezú” személyekre bízzák a közbeszerzések ügyeinek az intézését - és tegyék lehetővé, hogy a megbízottak rendszeres továbbképzés során megismerjék a korrupcióellenes küzdelem új és új meggondolásait, módszereit.

- Hozzák létre a részvételükkel megindult közbeszerzési eljárások monitoringrendszerét, s ennek keretében épitsenek ki a korrupció veszélyére figyelmeztetó alrendszert. 
Az utóbbi ajánlást különösen idôszerúnek ítéljük. Az alábbi ábra azt mutatja ugyanis, hogy az eljárásokkal kapcsolatosan korrupciós gyanút érzékelő, illetve nem érzékelő interjúadók - a GKI-mélyinterjúk során kapott válaszok szerint - milyen arányban jelezték az eljárások ellenórzését. S úgy túnik, a jelenlegi hazai gyakorlatnak kiemelkedően kedvezôtlen eleme, hogy a korrupció gyanúja inkább csökkenti, mint növeli az ellenőrzési törekvések gyakoriságát.

Végül a tanulmány szerzői a magyar gazdaság minden szereplójének (a vállalatoknak is, de a makroszférának is) megfogalmaztak egy ajánlást. Fontosnak tartják ugyanis, hogy minden szinten nézzünk szembe - önkritikusan is - a problémával. Félrevezető, sôt, esetenként a saját szennyes takargatása, ha a korrupció gyanújával, illetve „közepes” szintjével kapcsolatos megállapításokat azzal söpörjük a szőnyeg alá, hogy rámutatunk: vannak mérési, bizonyítási nehézségek, illetve nálunk rosszabb helyzetú gazdaságok (vagy vállalatok). A gondok e leplezése csak a megoldást nehezíti (2. ábra).

\section{Lábjegyzet}

${ }^{1}$ A korrupció, és a közbeszerzési korrupció Magyarországon. GKIKT. 2009. Az elemzéseket készítették: dr. Ács Ferenc, Andrási Zoltán, dr. Borsi Balázs, Kis Gergely, Némethné Pál Katalin, dr. Papanek Gábor, Papanek Zsuzsanna, dr. Sebestyén Tibor, Timár Szabolcs. Szerkesztette: dr. Papanek Gábor. www.kozbeszerzes. hu/ éves beszámolók és egyéb tájékoztatók/közbeszezési korrupciós kutatás

${ }^{2}$ Hankiss E. ugyanis ...,,azt is nyomatékosította, hogy a korrupció ügyében csak akkor érdemel figyelmet szavunk, ha a magyarországi korrupcióról van érdemi mondanivalónk. Nem érdemes a korrupció elméleti irodalmával babrálni ..." (Gombár, 1998: 47. oldal).

${ }^{3}$ TI $(2007,2008)$.

${ }^{4}$ Ismert állítás, hogy a korrupció a közbeszerzési eljárások 90\%ánál megjelenik. Lásd: Freedom House (2006), Transparency International Magyarország (2008), 1. oldal.

${ }^{5}$ A közpénzek költésével kapcsolatos - nagy - korrupciós cselekmények gyökerei a nemzetközi szakirodalom, így Miller Roberts - Spence (2005) szerint is általában a hatalommal való visszaélésekre vezethetốk vissza.

${ }^{6}$ Hankiss (1983).

${ }^{7}$ Mauro (1995).

${ }^{8}$ Például: Papanek (2000).

${ }^{9}$ A témára vonatkozó (empirikus) kutatási eredményeknek kitúnó összefoglalóját adja a Rose-Ackermann (2006) kézikönyv.

${ }^{10}$ Az OECD (2007) a nagyobb nemzetközi tenderek esetén a kenópénzek összegét a megbízási díj 5-20\%-ára becsüli (s mivel e díjat ma már nem lehet az igazi célt megnevezve lekönyvelni, a túlszámlázást hamis indokok alapján - például tanácsadói díjként, felesleges és el se végzett részfeladatok ráfordításaiként stb. - számolják el). A korrupcióval erôsen fertőzött országokban azonban nem ritka a lényegesen magasabb „baksis” - s az 50\%os ,jatt” a magyar gazdaságban sem ismeretlen már.

${ }^{11}$ „Miután az állam képviselói az árajánlatok részleteit nem hozzák nyilvánosságra a kivitelezók ,,̈̈zleti érdekeinek védelmé- ben”, az újságíró kénytelen arra támaszkodni, amit kézen-közön megtud a titkolt adatokból, ha hozzávetőleges képet szeretne kapni arról, mennyi közpénz folyt ki „feleslegesen” az államkasszából az elmúlt években. Bár a kilométerre lebontott fajlagos költségek is árulkodók, az indokolatlan túlszámlázásokat egyértelmúvé az egységárak összevetése teheti. Egy példa: A kartellbotrányban érintett, 2002-es közbeszerzési eljárás egyik beruházása az M3-as Polgár-Görbeháza közötti szakaszának építése volt. Mint az árajánlat máig titkolt részleteiból kiderül, az aszfalt kopórétegének köbméterét itt több mint 75 ezer forintért adta el a magyar államnak a nyertes, ugyanaz a cég, amely három évvel késôbb, 2005 végén, az M0-s továbbépítésében is szerepet kapott. A körgyưrú le- és felhajtóira - jelentős alapanyag-drágulást követóen - a társaság információink szerint 38 ezer forintért számlázza ki ugyanazt az aszfaltot." Népszabadság, 2006. 08. 26.

${ }^{12}$ Például: az ENSZ-konvenció (lásd a 2000. évi XXXII. Törvényt); az OECD (1997) konvenciója (szintén elfogadtuk) és dokumentuma; az Unió több kiadványa stb.

${ }^{13}$ A hozzászólások többnyire a makrogondokat ítélték a fő problémának (a „fejétől búzlik a hal” elv alapján). Mind a sajtófeldolgozás, mind az interjúk csaknem általános elégedetlenséget tükröztek a közbeszerzési törvénnyel és a korrupció elleni szabályokkal kapcsolatosan is. A törvény leggyakrabban bonyolultsága, bürokratizmusa, nehéz megérthetôsége miatt kapott bírálatot, s a javaslatok a jelentôs egyszerúsítést sürgették. A korrupció elleni szabályok viszont fóként alacsony hatékonyságuk miatt keltettek elégedetlenséget, s a szankciók szigorítása, illetve ezeknek a nagy ügyek esetében történő érvényesítése voltak a legtöbbször említett ajánlások.

\section{Felhasznált irodalom}

Freedom House (2006): Nations in Transit

Gombár Cs. (1998): A korrupció, mint közrossz. In: Írások a korrupcióról. Helikon-Korridor

Hankiss E. (1983): Társadalmi csapdák. Diagnózisok. Magvető Mauro P. (1995): Corruption and Growth. Quarterly Journal of Economics. No. 3.

Miller, S. - Roberts, P. - Spence, E. (2005): Corruption and Anti-corruption. Pearson. Upper Saddle River, NJ

OECD (2007): Bribery in Public Procurement: Methods, Actors and Counter-Measures. Paris

Papanek G. (2000): Corruption in the international transactions. GKI Rt.. Összefoglaló magyarul: Nemzetközi tranzakciók monitoringjának problémái. In: Kopcsik K. (szerk.): Nemzetközi konferencia a tisztább közéletért. ENSZ - MEH. 2003. Újranyomva: Belügyi Szemle. 2003. 9. sz.

Rose-Ackerman, S. (ed.) (2006): International Handbook on the Economics of Corruption. Edgar Elgar. Cheltenham

TI (Transparency International) (2007, 2008): Global Corruption Report 2007, 2008. Pluto Press. London

TI Magyarország (2008): Állásfoglalás a közbeszerzések helyzetéról. Budapest

Cikk beérkezett: 2009. 12. hó

Lektori vélemény alapján véglegesítve: 2010. 1. hó 